\title{
Soluble trace metals in aerosols over the tropical south-east Pacific offshore of Peru
}

\author{
A. R. Baker ${ }^{1}$, M. Thomas ${ }^{1}$, H. W. Bange ${ }^{2}$, and E. Plasencia Sánchez ${ }^{3}$ \\ ${ }^{1}$ Centre for Ocean and Atmospheric Science, School of Environmental Sciences, University of East Anglia, \\ Norwich, NR4 7TJ, UK \\ ${ }^{2}$ Marine Biogeochemie, GEOMAR Helmholtz-Zentrum für Ozeanforschung Kiel, Düsternbrooker Weg 20, \\ 24105 Kiel, Germany \\ ${ }^{3}$ Facultad de Ingeniería Geológica, Minera y Metalúrgica, Universidad Nacional de Ingeniería, Peru Dirección General de \\ Investigación y Asuntos Ambientales, Servicio Nacional de Meteorología e Hidrología del Perú, SENAMHI, Lima, Peru
}

Correspondence to: A. R. Baker (alex.baker@uea.ac.uk)

Received: 1 October 2015 - Published in Biogeosciences Discuss.: 27 October 2015

Revised: 20 January 2016 - Accepted: 28 January 2016 - Published: 12 February 2016

\begin{abstract}
Bulk aerosol samples collected during cruise M91 of FS Meteor off the coast of Peru in December 2012 were analysed for their soluble trace metal (Fe, $\mathrm{Al}, \mathrm{Mn}, \mathrm{Ti}, \mathrm{Zn}$, $\mathrm{V}, \mathrm{Ni}, \mathrm{Cu}, \mathrm{Co}, \mathrm{Cd}, \mathrm{Pb}, \mathrm{Th}$ ) and major ion (including $\mathrm{NO}_{3}^{-}$ and $\mathrm{NH}_{4}^{+}$) content. These data are among the first recorded for trace metals in this relatively poorly studied region of the global marine atmosphere. To the north of $\sim 13^{\circ} \mathrm{S}$, the concentrations of several elements (Fe, Ti, $\mathrm{Zn}, \mathrm{V}, \mathrm{Ni}, \mathrm{Pb}$ ) appear to be related to distance from the coast. At the south of the transect $\left(\sim 15-16^{\circ} \mathrm{S}\right)$, elevated concentrations of $\mathrm{Fe}, \mathrm{Cu}$, $\mathrm{Co}$, and $\mathrm{Ni}$ were observed, and we calculated dry deposition fluxes of soluble $\mathrm{Cu}$ approximately an order of magnitude higher than a recent model-based estimate of total $\mathrm{Cu}$ deposition to the region. The model did not take account of emissions from the large smelting facilities in the south of Peru and northern Chile, and our results may indicate that these facilities constitute an important source of trace metals to the region. Calculated dry deposition fluxes (3370-17800 and 16-107 nmol m ${ }^{-2} \mathrm{~d}^{-1}$ for inorganic nitrogen and soluble Fe respectively) indicated that atmospheric input to the waters of the Peru upwelling system contains an excess of Fe over $\mathrm{N}$, with respect to phytoplankton requirements. This may be significant as primary production in these waters has been reported to be limited by $\mathrm{Fe}$ availability, but atmospheric deposition is unlikely to be the dominant source of Fe to the system.
\end{abstract}

\section{Introduction}

Aerosol chemical composition plays a key role in a number of processes that are important for climate regulation, including the formation of cloud condensation nuclei (Raes et al., 2000) and the supply of nutrients such as nitrogen (N), phosphorus $(\mathrm{P})$, and iron $(\mathrm{Fe})$, as well as other trace metals to the ocean (Okin et al., 2011).

Few studies of the atmosphere over the south-eastern Pacific Ocean have been conducted and, compared to other ocean regions (e.g. the North Atlantic, northwest Pacific and northern Indian oceans), rather little is known about its aerosol chemical composition. The coastal region of Peru and northern Chile contains some strong sources of aerosols including the megacity of Lima with its associated urban/industrial combustion emissions (nitrogen and sulfur oxides, trace metals), industrial and informal mining (mineral dust), several large metal smelting facilities (trace metals, sulfur dioxide), arid areas (mineral dust), and active volcanoes (sulfur dioxide, mineral dust). The region is heavily influenced by the high Andes mountain chain, which forces surface winds into a strong south-easterly flow roughly parallel to the coast (Wood et al., 2011). This wind system in turn drives coastal upwelling offshore of Peru and Chile, supplying nutrients which support intense primary productivity in surface waters. Previous ship- and satellite-based observations have identified a strong gradient in aerosol concentrations in the region, with very low concentrations offshore and higher concentrations near the coast (Hawkins et al., 2010), 


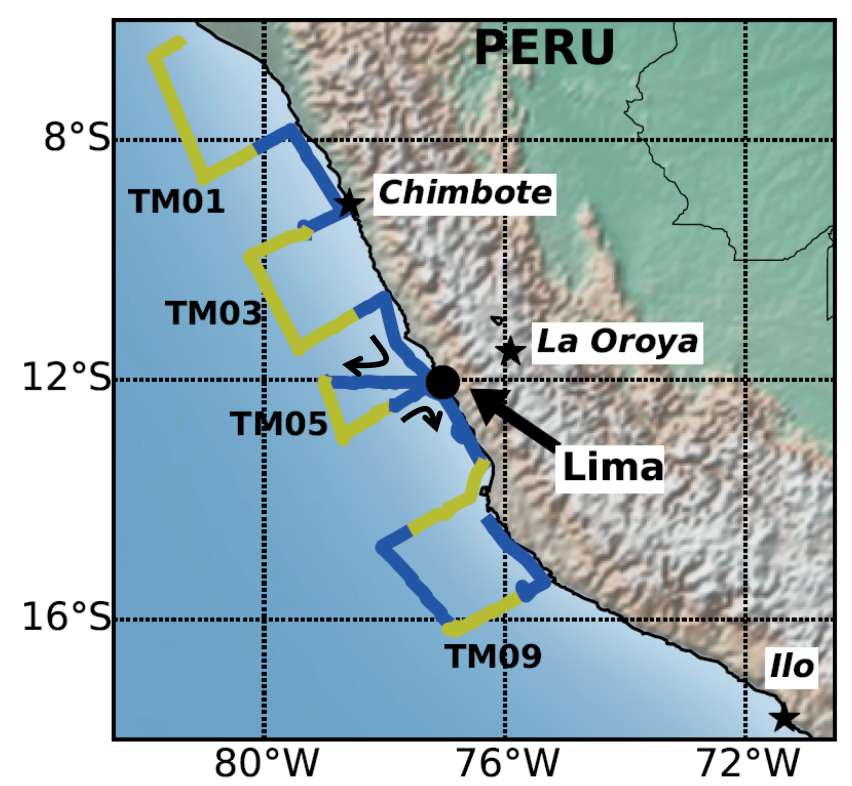

Figure 1. Track of cruise M91, showing locations of aerosol samples TM01-TM10 as alternating colours along the track. Also shown are the locations of the megacity of Lima and the smelters at Chimbote, La Oroya, and Ilo.

and the surface and vertical distributions of manganese (Mn) in the waters of the Peruvian shelf have been interpreted to suggest that Mn has a significant atmospheric source here (Vedamati et al., 2015). There is, however, very little data available on the chemical composition of aerosol material in this region (particularly for trace metals) or the impact that deposition of this material has on surface-water nutrient dynamics.

Here we report concentrations of aerosol soluble trace metals and major ions in samples collected off the coast of Peru during December 2012. We examine the possible sources of this material and its potential impact on the waters into which it is deposited.

\section{Methods}

Aerosol samples were collected between 4 and 24 December 2012 during cruise M91 of the FS Meteor off the coast of Peru (Fig. 1). A volumetric-flow-controlled total suspended particulate collector was used, operating at a flow rate of $1.1 \mathrm{~m}^{3} \mathrm{~min}^{-1}$. Operation of the collector was controlled by an automated wind sector controller, which interrupted pumping if the relative wind speed was below $2 \mathrm{~m} \mathrm{~s}^{-1}$ or the relative wind direction was within an $\operatorname{arc} 45^{\circ}$ either side of the ship's stern. Each sample was deployed in the collector for a period of $\sim 48 \mathrm{~h}$, giving maximum air volumes filtered of $\sim 3200 \mathrm{~m}^{3}$. Sample collection details are given in Table 1. Samples were collected on $20.3 \times 25.4 \mathrm{~cm}$ Whatman 41 filters that had previously been washed using dilute

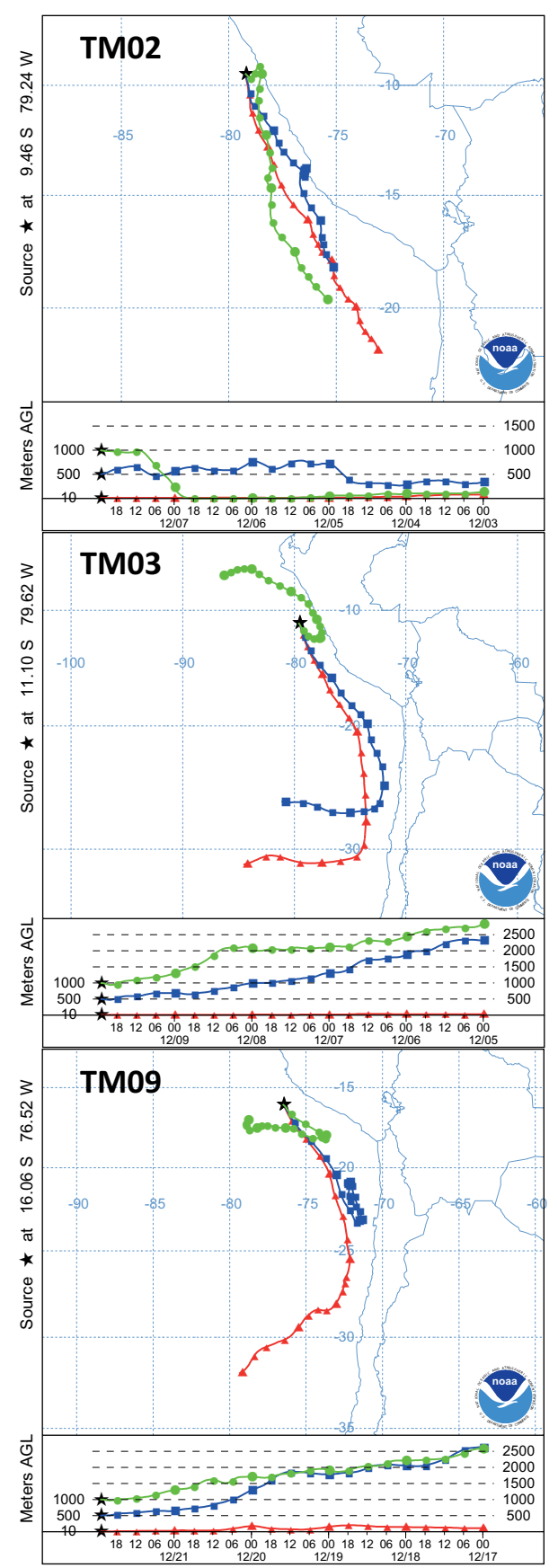

Figure 2. Example 5-day air mass back trajectories for the midpoints of samples TM02, TM03, and TM09.

$(0.5$ and $0.1 \mathrm{M}) \mathrm{HCl}$ solutions and ultrapure water to reduce trace metal contamination (Rickli et al., 2010). Contributions from blanks were assessed by analysis of filters that had been housed in the sampling cassette for $24 \mathrm{~h}$, but not deployed in the collector, and of filters that had been deployed in the collector for $48 \mathrm{~h}$ without air pumping.

After collection, aerosol filters were sealed in ziplock plastic bags and returned frozen to the University of East An- 
Table 1. Details of aerosol samples collected during the M91 cruise.

\begin{tabular}{llllll}
\hline Sample & Start date & Start position & End date & End position & Air volume $\left(\mathrm{m}^{3}\right)$ \\
\hline TM01 & $4 / 12 / 2012$ & $6.37^{\circ} \mathrm{S}, 81.43^{\circ} \mathrm{W}$ & $6 / 12 / 2012$ & $8.11^{\circ} \mathrm{S}, 80.07^{\circ} \mathrm{W}$ & 2858.5 \\
TM02 & $6 / 12 / 2012$ & $8.10^{\circ} \mathrm{S}, 80.06^{\circ} \mathrm{W}$ & $8 / 12 / 2012$ & $9.57^{\circ} \mathrm{S}, 79.32^{\circ} \mathrm{W}$ & 2339.0 \\
TM03 & $8 / 12 / 2012$ & $9.57^{\circ} \mathrm{S}, 79.32^{\circ} \mathrm{W}$ & $10 / 12 / 2012$ & $10.84^{\circ} \mathrm{S}, 78.38^{\circ} \mathrm{W}$ & 3089.5 \\
TM04 & $10 / 12 / 2012$ & $10.84^{\circ} \mathrm{S}, 78.38^{\circ} \mathrm{W}$ & $12 / 12 / 2012$ & $12.04^{\circ} \mathrm{S}, 79.00^{\circ} \mathrm{W}$ & 2563.4 \\
TM05 & $12 / 12 / 2012$ & $12.04^{\circ} \mathrm{S}, 79.00^{\circ} \mathrm{W}$ & $14 / 12 / 2012$ & $12.42^{\circ} \mathrm{S}, 77.81^{\circ} \mathrm{W}$ & 3002.3 \\
TM06 & $14 / 12 / 2012$ & $12.42^{\circ} \mathrm{S}, 77.81^{\circ} \mathrm{W}$ & $16 / 12 / 2012$ & $13.43^{\circ} \mathrm{S}, 76.37^{\circ} \mathrm{W}$ & 2267.1 \\
TM07 & $16 / 12 / 2012$ & $13.43^{\circ} \mathrm{S}, 76.37^{\circ} \mathrm{W}$ & $18 / 12 / 2012$ & $14.56^{\circ} \mathrm{S}, 77.66^{\circ} \mathrm{W}$ & 3099.4 \\
TM08 & $18 / 12 / 2012$ & $14.57^{\circ} \mathrm{S}, 77.67^{\circ} \mathrm{W}$ & $20 / 12 / 2012$ & $16.16^{\circ} \mathrm{S}, 76.83^{\circ} \mathrm{W}$ & 2795.1 \\
TM09 & $20 / 12 / 2012$ & $16.16^{\circ} \mathrm{S}, 76.82^{\circ} \mathrm{W}$ & $22 / 12 / 2012$ & $15.54^{\circ} \mathrm{S}, 75.62^{\circ} \mathrm{W}$ & 3121.8 \\
TM10 & $22 / 12 / 2012$ & $15.54^{\circ} \mathrm{S}, 75.62^{\circ} \mathrm{W}$ & $24 / 12 / 2012$ & $14.37^{\circ} \mathrm{S}, 76.25^{\circ} \mathrm{W}$ & 2015.0
\end{tabular}

glia (UEA). All handling of filters at UEA was done within a laminar flow hood in a trace metal clean laboratory. Filters were quartered using ceramic-bladed scissors, and onequarter each was used for analysis of major ions (MIs: $\mathrm{Na}^{+}, \mathrm{NH}_{4}^{+}, \mathrm{Mg}^{2+}, \mathrm{K}^{+}, \mathrm{Ca}^{2+}, \mathrm{Cl}^{-}, \mathrm{NO}_{3}^{-}, \mathrm{SO}_{4}^{2-}, \mathrm{C}_{2} \mathrm{O}_{4}^{2-}$, $\mathrm{Br}^{-}$) and soluble trace metals (TMs: Fe, Al, Mn, Ti, Zn, $\mathrm{V}, \mathrm{Cu}, \mathrm{Ni}, \mathrm{Co}, \mathrm{Cd}, \mathrm{Pb}, \mathrm{Th})$. Major ions were extracted into $20 \mathrm{~mL}$ of ultrapure water using $60 \mathrm{~min}$ of ultrasonication, filtered $(0.2 \mu \mathrm{m}$; Sartorius $)$ and analysed by ion chromatography (Baker et al., 2007). Soluble TMs were extracted using a batch method into $20 \mathrm{~mL}$ pH 4.7 ammonium acetate buffer prepared from TraceSELECT Ultra ammonium hydroxide and acetic acid solutions (Sigma-Aldrich). Extractions were terminated by filtration $(0.2 \mu \mathrm{m}$; Sartorius $)$, and TM concentrations were determined by ICP-OES (Fe, Al, $\mathrm{Mn}, \mathrm{Ti}, \mathrm{Zn}, \mathrm{V}$ ) and ICP-MS (Mn, V, Cu, Ni, Co, Cd, Pb, $\mathrm{Th})$. Instruments were calibrated using matrix-matched standard solutions prepared from single-element SPEX CertiPrep $1000 \mathrm{mg} \mathrm{L}^{-1}$ standard solutions. The Certified Reference Materials TMRAIN-04, TM-27.3, and TMDA-64.2 (Environment Canada) were analysed together with TM samples. Recoveries for these CRMs were within the following limits of their certified values: TMRAIN-04 $\pm 10 \%(\mathrm{Mn}, \mathrm{Cu})$, $\pm 15 \%(\mathrm{Ni}, \mathrm{Co}, \mathrm{Fe}), \pm 20 \%(\mathrm{Ti}, \mathrm{Zn}) ; \mathrm{TM}-27.3 \pm 5 \%(\mathrm{Cu}$, $\mathrm{Ni}, \mathrm{Co}, \mathrm{Pb}, \mathrm{Ti}), \pm 10 \%(\mathrm{Mn}, \mathrm{V}), \pm 20 \%$ (Cd, Fe, Al, Zn); TMDA-64.2 $\pm 5 \%$ (Mn, Cu, Co, Ti), $\pm 10 \%$ (V, Ni, Pb, Fe, $\mathrm{Zn})$, and $\pm 20 \%(\mathrm{Cd}, \mathrm{Al})$.

Quantities of analytes on each filter $\left(Q_{x}\right)$ were calculated from measured concentrations in extracts $\left(C_{x}^{\mathrm{e}}\right)$, extraction volumes $\left(V^{\mathrm{e}}\right)$, and the fraction of filter extracted $(f$; see Eq. 1), corrected for blank contributions $\left(Q_{x}^{\mathrm{b}}\right)$ and converted into atmospheric concentrations $\left(C_{x}^{\text {at }}\right)$ using the air volume for each sample ( $\left.V^{\text {air }}\right)$ (Eq. 2):

$Q_{x}=C_{x}^{\mathrm{e}} V^{\mathrm{e}} / f$,

$C_{x}^{\mathrm{at}}=\left(Q_{x}-Q_{x}^{\mathrm{b}}\right) / V^{\mathrm{air}}$.

For $\mathrm{K}^{+}, \mathrm{Ca}^{2+}$, and $\mathrm{SO}_{4}^{2-}$ we calculated the contribution to measured concentrations arising from sea spray using the measured aerosol $\mathrm{Na}^{+}$concentrations and the ratio of each ion to $\mathrm{Na}^{+}$in seawater $\left(\mathrm{C}^{\mathrm{sw}}\right)$. We then subtracted this sea spray contribution from the measured concentration to obtain the non-sea-spray (nss) concentration for each ion:

$\mathrm{nss}-C_{x}^{\mathrm{at}}=C_{x}^{\mathrm{at}}-\left(C_{\mathrm{Na}}^{\mathrm{at}} C_{x}^{\mathrm{sw}} / C_{\mathrm{Na}}^{\mathrm{sw}}\right)$.

Dry deposition fluxes $\left(F^{\mathrm{d}}\right)$ were estimated from atmospheric concentrations using dry deposition velocities $\left(v_{\mathrm{d}}\right)$ (Eq. 4$)$. Dry deposition velocities are highly variable with particle size and wind speed and rather poorly known. Duce et al. (1991) estimated the uncertainty in dry deposition velocities to be approximately a factor of 2-3.

$F_{x}^{\mathrm{d}}=C_{x}^{\mathrm{at}} v_{\mathrm{d}}$

Given the lack of aerosol size distribution data available for this region of the global ocean, we used fixed values of $v_{\mathrm{d}}$ for species predominantly associated with sea spray or mineral dust aerosol $\left(0.6 \mathrm{~cm} \mathrm{~s}^{-1}: \mathrm{NO}_{3}^{-}, \mathrm{Fe}, \mathrm{Al}, \mathrm{Mn}, \mathrm{Ti}, \mathrm{Co}, \mathrm{Th}\right)$ or for species predominantly associated with fine-mode aerosols $\left(0.1 \mathrm{~cm} \mathrm{~s}^{-1}: \mathrm{NH}_{4}^{+}, \mathrm{Zn}, \mathrm{V}, \mathrm{Cu}, \mathrm{Ni}, \mathrm{Cd}, \mathrm{Pb}\right)$.

Where we investigated correlations between parameters we reported these as significant using Spearman's rank correlation at the $99 \%$ confidence level. We obtained 5-day air mass back trajectories at heights of 10500 and $1000 \mathrm{~m}$ above the ship's position and ground-level 2-day forward trajectories from the sites of the Chimbote and Ilo smelters from the NOAA Air Resources Laboratory HYSPLIT model using the GDAS data set.

\section{Results and discussion}

The M91 cruise track (Fig. 1) consisted of a series of transects perpendicular to the coast. This resulted in samples TM01, TM03, and TM05 being collected far from shore and samples TM02, TM04, and TM06 being collected close to the coast. We refer to these different sample types as "offshore" and "nearshore" respectively. Air mass back trajectories for all the M91 aerosol samples indicated that surface flow was approximately south-south-easterly, consistent 
Table 2. Concentrations of aerosol soluble trace metals during the M91 cruise.

\begin{tabular}{|c|c|c|c|c|c|c|c|c|c|c|c|c|}
\hline Sample & $\begin{array}{r}\mathrm{Fe} \\
\mathrm{pmol} \mathrm{m}^{-3}\end{array}$ & $\mathrm{pmol} \mathrm{m}^{-3}$ & $\begin{array}{r}\mathrm{Mn} \\
\mathrm{pmol} \mathrm{m}^{-3}\end{array}$ & $\mathrm{pmol} \mathrm{m}^{-3}$ & $\mathrm{pmol} \mathrm{m}^{-3}$ & $\mathrm{pmol} \mathrm{m}^{-3}$ & $\mathrm{pmol} \mathrm{m}^{-3}$ & $\mathrm{pmol} \mathrm{m}^{\mathrm{Ni}}$ & $\begin{array}{r}\text { Co } \\
\mathrm{pmol} \mathrm{m}^{-3}\end{array}$ & $\begin{array}{r}\mathrm{Cd} \\
\mathrm{pmol} \mathrm{m}^{-3}\end{array}$ & $\begin{array}{r}\mathrm{Pb} \\
\mathrm{pmol} \mathrm{m}^{-3}\end{array}$ & $\begin{array}{r}\text { Th } \\
\text { fmol m}^{-3}\end{array}$ \\
\hline TM01 & $41.3 \pm 0.8$ & $202.2 \pm 3.2$ & $12.4 \pm 0.7$ & $0.09 \pm 0.02$ & $8.3 \pm 2.1$ & $9.9 \pm 2.5$ & $113.6 \pm 0.3$ & $3.04 \pm 0.03$ & $0.187 \pm 0.003$ & $<0.22$ & $1.27 \pm 0.01$ & $9.7 \pm 0.5$ \\
\hline TM02 & $128.3 \pm 0.9$ & $502.2 \pm 3.9$ & $20.4 \pm 0.5$ & $0.24 \pm 0.08$ & $54.1 \pm 2.5$ & $37.9 \pm 0.2$ & $68.1 \pm 0.2$ & $11.17 \pm 0.05$ & $0.403 \pm 0.003$ & $0.924 \pm 0.004$ & $7.34 \pm 0.02$ & $18.5 \pm 0.7$ \\
\hline TM03 & $59.4 \pm 1.4$ & $289.3 \pm 4.1$ & $20.2 \pm 2.0$ & $0.10 \pm 0.02$ & $8.8 \pm 1.7$ & $10.9 \pm 0.2$ & $116.6 \pm 0.5$ & $3.67 \pm 0.03$ & $0.395 \pm 0.007$ & $0.335 \pm 0.003$ & $2.00 \pm 0.01$ & $21.1 \pm 0.9$ \\
\hline TM04 & $78.4 \pm 0.8$ & $289.1 \pm 3.6$ & $17.7 \pm 0.7$ & $0.20 \pm 0.05$ & $46.4 \pm 2.3$ & $51.2 \pm 0.2$ & $80.0 \pm 0.2$ & $13.64 \pm 0.05$ & $0.406 \pm 0.002$ & $0.432 \pm 0.002$ & $3.97 \pm 0.01$ & $11.3 \pm 0.7$ \\
\hline TM05 & $58.2 \pm 0.7$ & $205.1 \pm 3.0$ & $18.2 \pm 1.2$ & $0.14 \pm 0.02$ & $18.7 \pm 2.0$ & $11.0 \pm 2.4$ & $97.1 \pm 0.2$ & $2.94 \pm 0.02$ & $0.337 \pm 0.002$ & $0.178 \pm 0.002$ & $1.77 \pm 0.01$ & $8.4 \pm 0.6$ \\
\hline TM06 & $154.6 \pm 0.9$ & $573.5 \pm 4.0$ & $30.8 \pm 0.8$ & $0.31 \pm 0.06$ & $51.9 \pm 2.6$ & $45.0 \pm 0.2$ & $233.1 \pm 0.6$ & $13.19 \pm 0.06$ & $0.554 \pm 0.003$ & $1.056 \pm 0.004$ & $6.20 \pm 0.02$ & $25.9 \pm 0.7$ \\
\hline TM07 & $41.5 \pm 0.7$ & $146.5 \pm 5.1$ & $10.6 \pm 0.8$ & $<0.04$ & $14.1 \pm 1.7$ & $11.4 \pm 0.1$ & $59.0 \pm 0.3$ & $3.62 \pm 0.03$ & $0.220 \pm 0.009$ & $<0.20$ & $1.01 \pm 0.01$ & $5.8 \pm 1.1$ \\
\hline TM08 & $31.5 \pm 2.0$ & $124.1 \pm 5.9$ & $12.0 \pm 0.9$ & $<0.05$ & $9.7 \pm 1.9$ & $6.7 \pm 0.1$ & $311.3 \pm 1.0$ & $2.45 \pm 0.03$ & $0.215 \pm 0.007$ & $<0.22$ & $1.07 \pm 0.01$ & $6.1 \pm 0.8$ \\
\hline TM09 & $206.2 \pm 0.7$ & $141 \pm 45$ & $16.7 \pm 1.3$ & $0.11 \pm 0.02$ & $<6.0$ & $8.2 \pm 2.2$ & $349.2 \pm 0.7$ & $59.6 \pm 0.2$ & $0.690 \pm 0.002$ & $<0.20$ & $0.86 \pm 0.01$ & $7.0 \pm 0.6$ \\
\hline TM10 & $67.5 \pm 1.0$ & $320 \pm 50$ & $11.8 \pm 1.4$ & $0.14 \pm 0.04$ & $14.9 \pm 2.9$ & $17.9 \pm 0.3$ & $71.3 \pm 0.1$ & $5.13 \pm 0.04$ & $0.192 \pm 0.003$ & $<0.31$ & $2.22 \pm 0.01$ & $6.9 \pm 0.9$ \\
\hline
\end{tabular}

Table 3. Concentrations of aerosol soluble major ions during the M91 cruise.

\begin{tabular}{|c|c|c|c|c|c|c|c|c|c|c|}
\hline Sample & $\begin{array}{r}\mathrm{Na}^{+} \\
\mathrm{nmol} \mathrm{m}{ }^{-3}\end{array}$ & $\begin{array}{r}\mathrm{NH}_{4}^{+} \\
\mathrm{nmol} \mathrm{m}^{-3}\end{array}$ & $\begin{array}{r}\mathrm{Mg}^{2+} \\
\mathrm{nmol} \mathrm{m}^{-3}\end{array}$ & $\begin{array}{r}\mathrm{K}^{+} \\
\mathrm{nmol} \mathrm{m}^{-3}\end{array}$ & $\begin{array}{r}\mathrm{Ca}^{2+} \\
\mathrm{nmol} \mathrm{m}^{-3}\end{array}$ & $\begin{array}{r}\mathrm{Cl}^{-} \\
\mathrm{nmol} \mathrm{m}^{-3}\end{array}$ & $\begin{array}{r}\mathrm{NO}_{3}^{-} \\
\mathrm{nmol} \mathrm{m}{ }^{-3}\end{array}$ & $\begin{array}{r}\mathrm{SO}_{4}^{2-} \\
\mathrm{nmol} \mathrm{m}^{-3}\end{array}$ & $\begin{array}{r}\mathrm{C}_{2} \mathrm{O}_{4}^{2-} \\
\mathrm{nmol} \mathrm{m}^{-3}\end{array}$ & $\begin{array}{r}\mathrm{Br}^{-} \\
\mathrm{nmol} \mathrm{m}^{-3}\end{array}$ \\
\hline TM01 & $41.2 \pm 0.7$ & $13.6 \pm 0.3$ & $4.3 \pm 0.1$ & $1.1 \pm 0.1$ & $1.6 \pm 0.1$ & $31.3 \pm 0.5$ & $9.2 \pm 0.1$ & $13.4 \pm 0.1$ & $0.18 \pm 0.01$ & $0.017 \pm 0.006$ \\
\hline TM03 & $130.4 \pm 2.6$ & $11.7 \pm 0.2$ & $14.3 \pm 0.2$ & $2.6 \pm 0.1$ & $4.7 \pm 0.2$ & $123.5 \pm 2.8$ & $7.0 \pm 0.2$ & $22.5 \pm 0.5$ & $0.21 \pm 0.02$ & $<0.035$ \\
\hline TM04 & $76.3 \pm 1.3$ & $34.0 \pm 0.5$ & $8.1 \pm 0.2$ & $2.1 \pm 0.1$ & $2.8 \pm 0.2$ & $75.4 \pm 0.5$ & $16.0 \pm 0.1$ & $19.1 \pm 0.1$ & $0.22 \pm 0.01$ & $<0.034$ \\
\hline TM05 & $66.3 \pm 1.6$ & $14.3 \pm 0.2$ & $6.7 \pm 0.3$ & $1.7 \pm 0.1$ & $2.4 \pm 0.3$ & $66.0 \pm 0.7$ & $5.8 \pm 0.3$ & $14.1 \pm 0.2$ & $0.15 \pm 0.02$ & $<0.032$ \\
\hline TM07 & $127.7 \pm 2.7$ & $20.1 \pm 0.3$ & $12.8 \pm 0.6$ & $3.1 \pm 0.2$ & $3.9 \pm 0.6$ & $120.0 \pm 1.2$ & $8.0 \pm 0.6$ & $25.5 \pm 0.3$ & $0.25 \pm 0.03$ & $<0.055$ \\
\hline TM08 & $70.7 \pm 2.2$ & $8.1 \pm 0.3$ & $7.7 \pm 0.3$ & $1.2 \pm 0.2$ & $2.6 \pm 0.2$ & $65.8 \pm 2.4$ & $5.2 \pm 0.3$ & $13.7 \pm 0.5$ & $0.16 \pm 0.03$ & $<0.039$ \\
\hline TM09 & $215.4 \pm 7.5$ & $5.2 \pm 0.9$ & $22.7 \pm 1.4$ & $5.2 \pm 0.3$ & $6.2 \pm 1.5$ & $228.2 \pm 1.6$ & $6.7 \pm 0.7$ & $28.0 \pm 0.4$ & $0.19 \pm 0.04$ & $<0.055$ \\
\hline TM10 & $108.0 \pm 2.4$ & $8.2 \pm 0.3$ & $10.9 \pm 0.5$ & $2.5 \pm 0.2$ & $3.5 \pm 0.5$ & $110.2 \pm 1.1$ & $5.4 \pm 0.5$ & $20.1 \pm 0.3$ & $0.10 \pm 0.04$ & $<0.047$ \\
\hline
\end{tabular}

with both the average wind directions recorded aboard ship for each sample $\left(144-168^{\circ}\right)$ and the climatological average flow for the region (Wood et al., 2011). Example trajectories for the mid-point of samples TM02 (nearshore), TM03 (offshore), and TM09 are shown in Fig. 2. A notable feature of these trajectories (which were run at intervals of $24 \mathrm{~h}$, i.e. twice per sample period) was that very few (for any start height) appeared to pass over South America.

Concentrations of soluble TMs and MIs determined for the aerosol samples collected during M91 are shown in Tables 2 and 3 respectively. We are aware of few previous studies of aerosol chemical composition in this region of the South Pacific. Hawkins et al. (2010) reported $\mathrm{SO}_{4}^{2-}$ concentrations in $<1 \mu \mathrm{m}$ diameter aerosol particles of $15 \pm 10 \mathrm{nmol} \mathrm{m}^{-3}$ in continentally influenced samples between $\sim 4$ and $\sim 20^{\circ} \mathrm{S}$ (although further offshore than M91) during the VOCALSREx field campaign in October-November 2008. Allen et al. (2011) reported $\mathrm{NH}_{4}^{+}$and $\mathrm{SO}_{4}^{2-}$ concentrations, also in $<1 \mu \mathrm{m}$ diameter particles and during VOCALS-REx, of 1639 and 2-9.4 $\mathrm{nmol} \mathrm{m}^{-3}$ respectively in samples collected between $\sim 85$ and $\sim 75^{\circ} \mathrm{W}$ at $20^{\circ} \mathrm{S}$. Although we report concentrations for bulk aerosol, rather than the sub-micron size fraction determined in these studies, their results are similar to those for M91 (Table 3), presumably because substantial fractions of both $\mathrm{NH}_{4}^{+}$and $\mathrm{SO}_{4}^{2-}$ are present in $<1 \mu \mathrm{m}$ diameter particles. Water-soluble concentrations of $\mathrm{Fe}, \mathrm{Al}, \mathrm{Mn}$, $\mathrm{Zn}$, and $\mathrm{Cu}$ were determined in $<1 \mu \mathrm{m}$ diameter aerosol particles near potential sources of mineral dust and anthropogenic emissions at Paposo, northern Chile $\left(25.007^{\circ} \mathrm{S}, 70.450^{\circ} \mathrm{W}\right)$, in October-November 2008 (Chand et al., 2010). Mean concentrations were reported to be $410,410,25,75$, and $88 \mathrm{pmol} \mathrm{m}^{-3}$ respectively for $\mathrm{Fe}, \mathrm{Al}, \mathrm{Mn}, \mathrm{Zn}$, and $\mathrm{Cu}$. Note that the data of Chand et al. (2010) are not directly comparable with our results from M91 because they were acquired using a different extraction protocol and a different sampling method. The trace metal fractions extracted in ammonium acetate and water may well be different (Morton et al., 2013), and the exclusion of larger aerosol particles in the Paposo samples would be expected to remove significant fractions of those elements strongly associated with mineral dust (Fe, $\mathrm{Al}$ and $\mathrm{Mn}$ ). Concentrations of soluble TMs measured during M91 were generally higher (by factors of 4 to 16 for V, $\mathrm{Ni}, \mathrm{Co}, \mathrm{Cd}$, and $\mathrm{Pb}$ ) than reported over the remote southeast Atlantic using nearly identical sampling and analysis methods to M91 (Chance et al., 2015). In the case of Cu, M91 concentrations were more than 50-fold higher than the concentrations measured by Chance et al. (2015).

In Fig. 3 we show aerosol nitrate concentrations as a function of sample number for the M91 cruise. This shows that $\mathrm{NO}_{3}^{-}$concentrations were approximately 2 -fold higher in the nearshore samples (TM02, TM04 and TM06) north of $\sim 13^{\circ} \mathrm{S}$ than in the offshore samples at those latitudes or in any of the samples south of $13^{\circ} \mathrm{S}$. Similar patterns were exhibited by many other analytes (see Tables 2 and 3), and this is in good qualitative agreement with the distribution of aerosol optical depth (AOD) in this region reported by Hawkins et al. (2010). These patterns gave rise to a number of significant correlations between analytes (e.g. be- 
Table 4. Spearman's rank correlation matrix for selected parameters measured during M91. Upper right quadrant (bold) shows significant correlation coefficients $(p<0.01)$ obtained from the entire data set. Lower left quadrant (italics) shows significant correlation coefficients $(p<0.01)$ obtained after removing sample TM09.

\begin{tabular}{|c|c|c|c|c|c|c|c|c|c|c|c|c|c|c|c|}
\hline & nss- $\mathrm{K}^{+}$ & nss-Ca ${ }^{2+}$ & nss-SO ${ }_{4}^{2-}$ & s-Fe & $\mathrm{s}-\mathrm{Al}$ & s-Mn & $\mathrm{s}-\mathrm{Ti}$ & $\mathrm{s}-\mathrm{Zn}$ & $\mathrm{s}-\mathrm{V}$ & $\mathrm{s}-\mathrm{Cu}$ & $\mathrm{s}-\mathrm{Ni}$ & s-Co & $\mathrm{s}-\mathrm{Cd}$ & $\mathrm{s}-\mathrm{Pb}$ & s-Th \\
\hline nss- $\mathrm{K}^{+}$ & $\mathbf{x}$ & & 0.78 & & & & 0.78 & & & & & & & & \\
\hline nss-Ca ${ }^{2+}$ & & $\mathbf{x}$ & & & & & & & & & & & & & \\
\hline nss-SO ${ }_{4}^{2-}$ & & 0.80 & $\mathbf{x}$ & & & & & & & & & & & & \\
\hline s-Fe ${ }^{4}$ & & & & $\mathbf{x}$ & & & 0.88 & & & & 0.93 & 0.84 & & & \\
\hline s-Al & & & & 0.93 & $\mathbf{x}$ & & & & 0.77 & & & & 0.88 & 0.92 & \\
\hline s-Mn & & & & & & $\mathbf{x}$ & & & & & & & & & 0.92 \\
\hline s-Ti & & & & 0.94 & 0.89 & & $\mathbf{x}$ & & & & 0.77 & & & & \\
\hline $\mathrm{s}-\mathrm{Zn}$ & 0.82 & & & 0.82 & & & 0.84 & $\mathbf{x}$ & 0.84 & & & & 0.78 & 0.83 & \\
\hline$s-V$ & 0.80 & & & 0.88 & & & 0.81 & 0.83 & $\mathbf{x}$ & & & & & 0.79 & \\
\hline $\mathrm{s}-\mathrm{Cu}$ & & & & & & & & & & $\mathbf{x}$ & & & & & \\
\hline s-Ni & & & & 0.90 & & & & & 0.92 & & $\mathbf{x}$ & 0.78 & & & \\
\hline s-Co & & & & & & & & & & & & $\mathbf{x}$ & & & \\
\hline $\mathrm{s}-\mathrm{Cd}$ & & & & 0.92 & 0.88 & 0.82 & 0.92 & & & & & 0.82 & $\mathbf{x}$ & 0.96 & 0.79 \\
\hline $\mathrm{s}-\mathrm{Pb}$ & & & & 0.93 & 0.92 & & 0.95 & & & & 0.82 & & 0.95 & $\mathbf{x}$ & \\
\hline s-Th & & & & & & 0.92 & & & & & & & 0.83 & & $\mathbf{x}$ \\
\hline
\end{tabular}

Table 5. Dry deposition fluxes ( $\mathrm{nmol} \mathrm{m} \mathrm{m}^{-2} \mathrm{~d}^{-1}$ ) of aerosol soluble components and the ratio of total inorganic nitrogen to soluble Fe deposition (TIN : Fe) during the M91 cruise. Deposition velocities used to calculate fluxes are described in the text.

\begin{tabular}{lrrrrrrrrrr}
\hline Sample & $\mathrm{NH}_{4}^{+}$ & $\mathrm{NO}_{3}^{-}$ & $\mathrm{Fe}$ & $\mathrm{Zn}$ & $\mathrm{Cu}$ & $\mathrm{Ni}$ & $\mathrm{Co}$ & $\mathrm{Cd}$ & $\mathrm{Pb}$ & $\mathrm{TIN}: \mathrm{Fe}$ \\
\hline TM01 & 1180 & 4750 & 21 & 0.7 & 9.8 & 0.3 & 0.10 & $<0.01$ & 0.11 & 280 \\
TM02 & 4240 & 13600 & 67 & 4.7 & 5.9 & 1.0 & 0.21 & 0.08 & 0.63 & 270 \\
TM03 & 1010 & 3650 & 31 & 0.8 & 10.1 & 0.3 & 0.20 & 0.03 & 0.17 & 150 \\
TM04 & 2940 & 8300 & 41 & 4.0 & 6.9 & 1.2 & 0.21 & 0.04 & 0.34 & 280 \\
TM05 & 1230 & 2300 & 30 & 1.6 & 8.4 & 0.3 & 0.17 & 0.02 & 0.15 & 140 \\
TM06 & 3350 & 11100 & 80 & 4.5 & 20.1 & 1.1 & 0.29 & 0.09 & 0.54 & 180 \\
TM07 & 1730 & 4160 & 21 & 1.2 & 5.1 & 0.3 & 0.11 & $<0.01$ & 0.09 & 270 \\
TM08 & 700 & 2670 & 16 & 0.8 & 26.9 & 0.2 & 0.11 & $<0.01$ & 0.09 & 210 \\
TM09 & 450 & 3460 & 107 & $<0.3$ & 30.2 & 5.1 & 0.36 & $<0.01$ & 0.07 & 37 \\
TM10 & 710 & 2830 & 35 & 1.3 & 6.2 & 0.4 & 0.10 & $<0.02$ & 0.19 & 100 \\
\hline
\end{tabular}

tween $\mathrm{NH}_{4}^{+}$and $\mathrm{NO}_{3}^{-}$) that are most likely caused by the co-location of emission sources, rather than by similar production/emission mechanisms for the analytes in question.

We observed significant correlations for several elements associated with mineral dust (Fe, Al, Mn, Ti, Co, Th: Fig. 4, Table 4). However for Co (Fig. 4a) and Fe, soluble concentrations appear to be enriched in sample TM09 relative to other dust-associated elements. Aerosol soluble $\mathrm{V}$ and $\mathrm{Ni}$ concentrations have previously been shown to be very highly correlated due to their emission during combustion of heavy fuel oils (Becagli et al., 2012). We find a similar close relationship between $\mathrm{s}-\mathrm{V}$ and $\mathrm{s}-\mathrm{Ni}$, again with the exception of sample TM09, which appears to be enriched in $\mathrm{Ni}$ (Fig. 5a). Although s-Cu does not appear to be related to s-V in our data set (Fig. 5b), it is notable that the highest $\mathrm{s}-\mathrm{Cu}$ concentrations were found in samples TM08 and TM09, in which most aerosol concentrations were relatively low. We consider that the most likely source of the elevated concentrations of $\mathrm{Cu}, \mathrm{Fe}, \mathrm{Co}$, and $\mathrm{Ni}$ we observed in sample
TM09 was emissions from the metal smelting facility at Ilo in southern Peru (Fig. 1), or perhaps from smelters located in central and northern Chile (Gidhagen et al., 2002; Paytan et al., 2009). Forward air mass trajectories run from Ilo (Fig. 6b) indicate that some of the emissions from the facility may have been advected over the ocean during the collection period of sample TM09. Satellite detections using the Ozone Monitoring Instrument (NASA EOS/Aura) in 20042005 were used to estimate $\mathrm{SO}_{2}$ emissions from the Ilo facility to be $\sim 0.3 \mathrm{Tg} \mathrm{yr}^{-1}$, equivalent to $\sim 25 \%$ of the combined $\mathrm{SO}_{2}$ emissions from the volcanoes in Ecuador and southern Colombia over the same period (Carn et al., 2007). However, improvements in sulfur capture efficiency at the smelter (Boon et al., 2001) were completed in 2007 and there is no elevation in nss- $\mathrm{SO}_{4}^{2-}$ concentration in sample TM09, compared to the other samples collected during the cruise (cruise range $9.5-26.3 \mathrm{nmol} \mathrm{m}^{-3}$, TM09 $15.0 \mathrm{nmol} \mathrm{m}^{-3}$ ). The copper smelter at La Oroya ceased operations in 2009 and was not active at the time of the M91 cruise. In any case, the ele- 


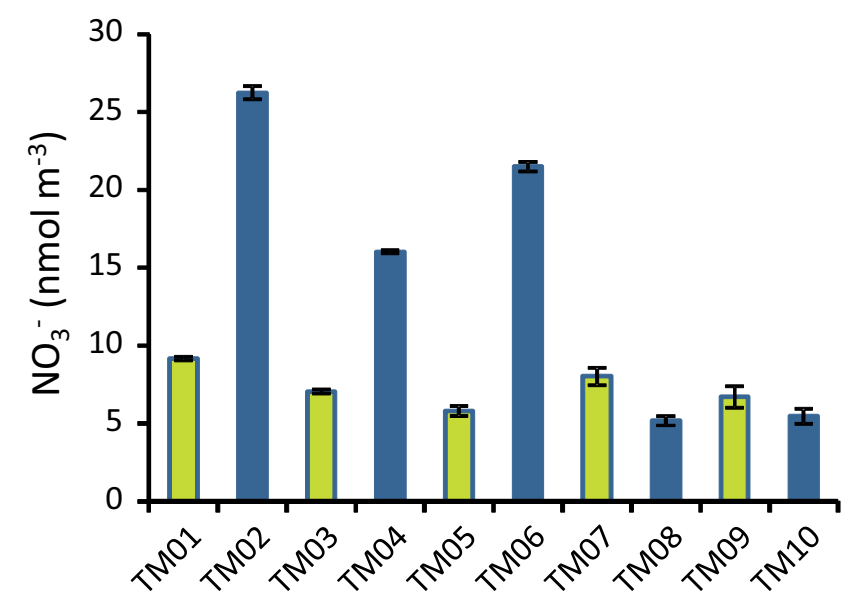

Figure 3. Aerosol nitrate concentrations $\left(\mathrm{nmol} \mathrm{m}^{-3}\right)$ during M91.

vation of the La Oroya site ( $~ 3750 \mathrm{~m}$ above sea level) and its surrounding mountains makes it unlikely to influence M91 aerosol concentrations. Emissions from the iron foundry at Chimbote may have contributed to the TM concentrations observed in sample TM02 (Fig. 6a).

In Table 5 we show calculated dry deposition fluxes of $\mathrm{NH}_{4}^{+}, \mathrm{NO}_{3}^{-}$, s-Fe, s-Co, s-Zn, s-Cu, s-Ni, s-Cd, s-Pb, and the ratio of total inorganic $\mathrm{N}\left(\mathrm{NH}_{4}^{+}+\mathrm{NO}_{3}^{-}\right)$to s$\mathrm{Fe}$ in dry deposition for the cruise. Dry deposition fluxes of $\mathrm{NH}_{4}^{+}$and $\mathrm{NO}_{3}^{-}$for the offshore and southerly samples were similar to average values calculated for the remote South Atlantic $\left(\mathrm{NH}_{4}^{+}: 600-800 \mathrm{nmol} \mathrm{m}^{-2} \mathrm{~d}^{-1}, \mathrm{NO}_{3}^{-}: 2300\right.$ $3400 \mathrm{nmol} \mathrm{m}^{-2} \mathrm{~d}^{-1}$; Baker et al., 2010), while fluxes for the northern nearshore samples were higher and similar to corresponding values for onshore winds on the west coast of Ireland $\left(\mathrm{NH}_{4}^{+}: 5100-9500 \mathrm{nmol} \mathrm{m}{ }^{-2} \mathrm{~d}^{-1}, \mathrm{NO}_{3}^{-}: 4200\right.$ $7500 \mathrm{nmol} \mathrm{m}^{-2} \mathrm{~d}^{-1}$; Spokes et al., 2000). The range of $\mathrm{NO}_{3}^{-}$ dry deposition fluxes calculated for M91 is in reasonable agreement with the results of a global modelling study for the region (Dentener et al., 2006), which indicated that the deposition of total $\mathrm{NO}_{y}$ (including gas-phase and wet deposition of oxidised $\mathrm{N}$ species) to the region was approximately 15 000-20000 nmol m $\mathrm{m}^{-2} \mathrm{~d}^{-1}$. In contrast to $\mathrm{N}$, dry deposition of s-Fe during M91 was 1-2 (for sample TM09) orders of magnitude higher than reported for the remote South Atlantic (2-7 nmol m${ }^{-2} \mathrm{~d}^{-1}$; Baker et al., 2013). Our average estimate of $\mathrm{F}_{\mathrm{s}-\mathrm{Fe}}^{\mathrm{d}}$ during M91 $\left(45 \mathrm{nmol} \mathrm{m}^{-2} \mathrm{~d}^{-1}\right.$, equivalent to $\sim 0.9 \mathrm{mg} \mathrm{m}^{-2} \mathrm{yr}^{-1}$ ) appears to be somewhat higher than the total deposition flux of s-Fe $\left(0.3 \mathrm{mg} \mathrm{m}^{-2} \mathrm{yr}^{-1}\right)$ estimated for the region by Krishnamurthy et al. (2009; as reported by Messie and Chavez, 2015). Atmospheric dust flux has been estimated from deep sea sediment records at the south of the M91 study region (IODP site 1237 at $\sim 16^{\circ} \mathrm{S}, 76^{\circ} \mathrm{W}$ ) to be equivalent to $\sim 1.1 \mathrm{mg} \mathrm{Fe} \mathrm{m}^{-2} \mathrm{~d}^{-1}$ (Saukel, 2011). Our estimates of soluble Fe dry deposition during M91 represent approximately $0.1-0.5 \%$ of the total $\mathrm{Fe}$ accumulation rate
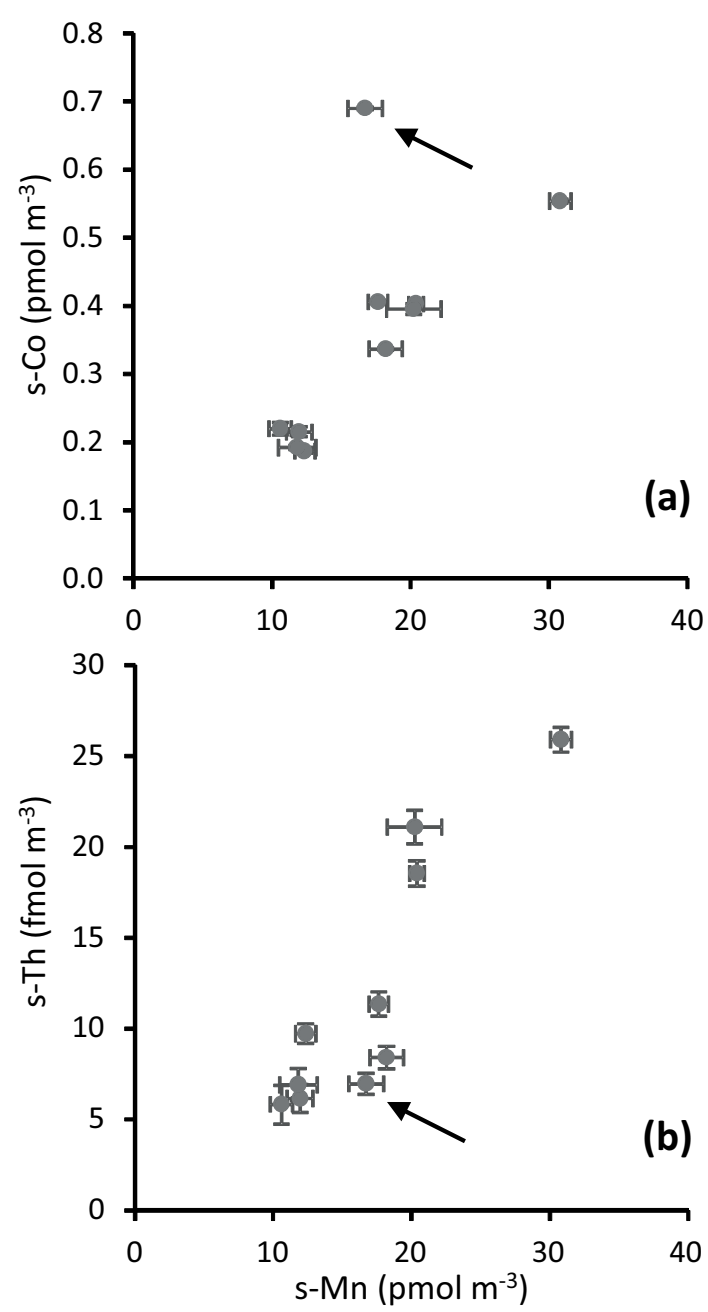

Figure 4. Plots of (a) soluble cobalt (s-Co) and (b) soluble thorium (s-Th) against soluble manganese (s-Mn) concentrations in M91 aerosol samples. Sample TM09 is indicated by an arrow in both panels.

at this site. These two deposition estimates are not directly comparable, since one is for total Fe deposition and the other is for soluble $\mathrm{Fe}$, and also because the estimate from the IODP core integrates atmospheric inputs over much longer timescales than those relevant to our aerosol samples. We have no information concerning the fractional solubility of aerosol $\mathrm{Fe}$ in this region, although analysis of Saharan dust over the Atlantic relatively close to source regions suggests that fractional solubility can be as low as $0.1-4 \%$ (Baker et al., 2006; Sholkovitz et al., 2012). Given these caveats, the comparison between the two deposition estimates does not seem unreasonable.

The range of TIN : s-Fe ratios in the M91 samples compares well to values of the total $\mathrm{N}$ : s-Fe ratio reported for the tropical Atlantic Ocean (170-1300; Baker et al., 2007) and implies that atmospheric deposition to the margins of the tropical eastern Pacific, as elsewhere in the global ocean, sup- 


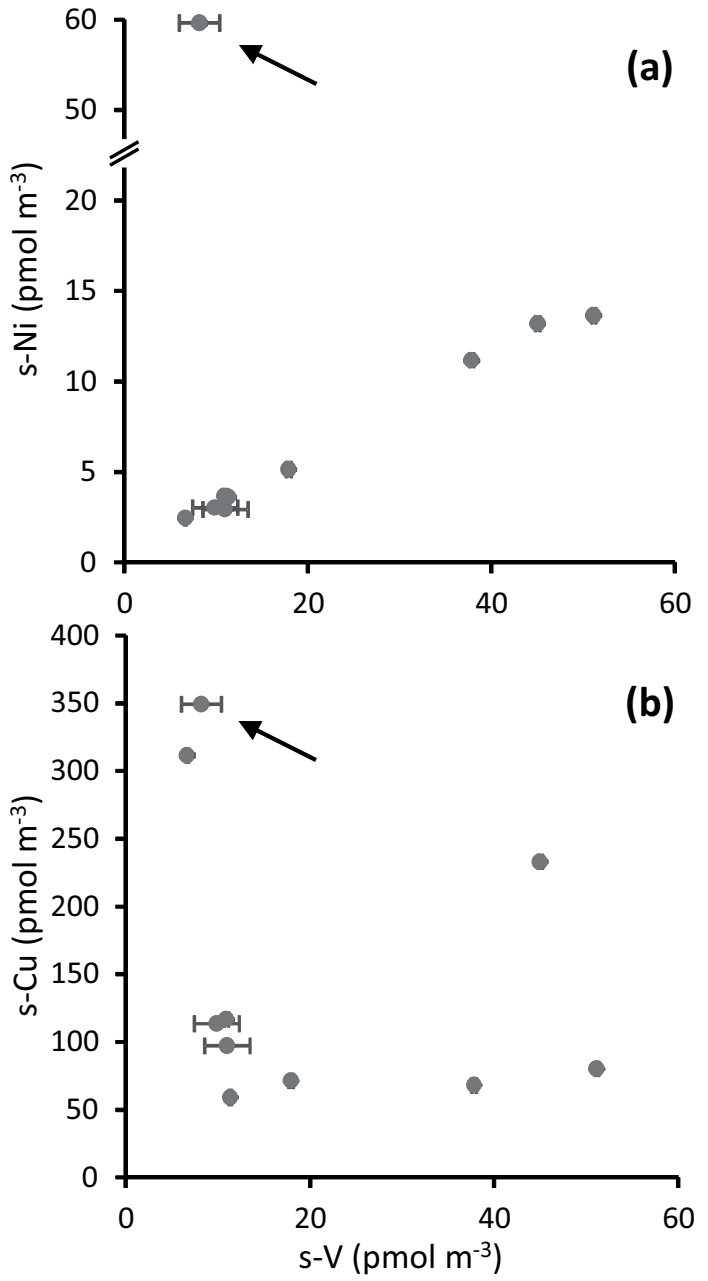

Figure 5. Plots of (a) soluble nickel (s-Ni) and (b) soluble copper $(\mathrm{s}-\mathrm{Cu})$ against soluble vanadium $(\mathrm{s}-\mathrm{V})$ concentrations in M91 aerosol samples. Sample TM09 is indicated by an arrow in both panels. Note the change in $y$ axis scale in (a).

plies $\mathrm{Fe}$ in excess (with respect to $\mathrm{N}$ supply) of the stoichiometric requirements of the phytoplankton community (Okin et al., 2011). This excess Fe supply from the atmosphere may be significant as primary production off the coast of Peru has been suggested to be limited by $\mathrm{Fe}$ availability (Bruland et al., 2005; Hutchins et al., 2002; Messie and Chavez, 2015). However, recent analysis indicates that dissolved $\mathrm{Fe}$ in the surface waters of the Peru upwelling system is isotopically lighter than $\mathrm{Fe}$ in known atmospheric sources, so atmospheric deposition is unlikely to be the dominant source of Fe in these waters (Chever et al., 2015).

Dissolved $\mathrm{Co}$ in the Peru upwelling system exhibits micronutrient-like behaviour, and Co speciation is linked to changes in phytoplankton assemblages there (Saito et al., 2004). Saito et al. (2004) suggested that Co input to the upwelling system was dominated by a sedimentary source of $\sim 19.9 \times 10^{6} \mathrm{~mol} \mathrm{yr}^{-1}$. Assuming an areal extent of the up-

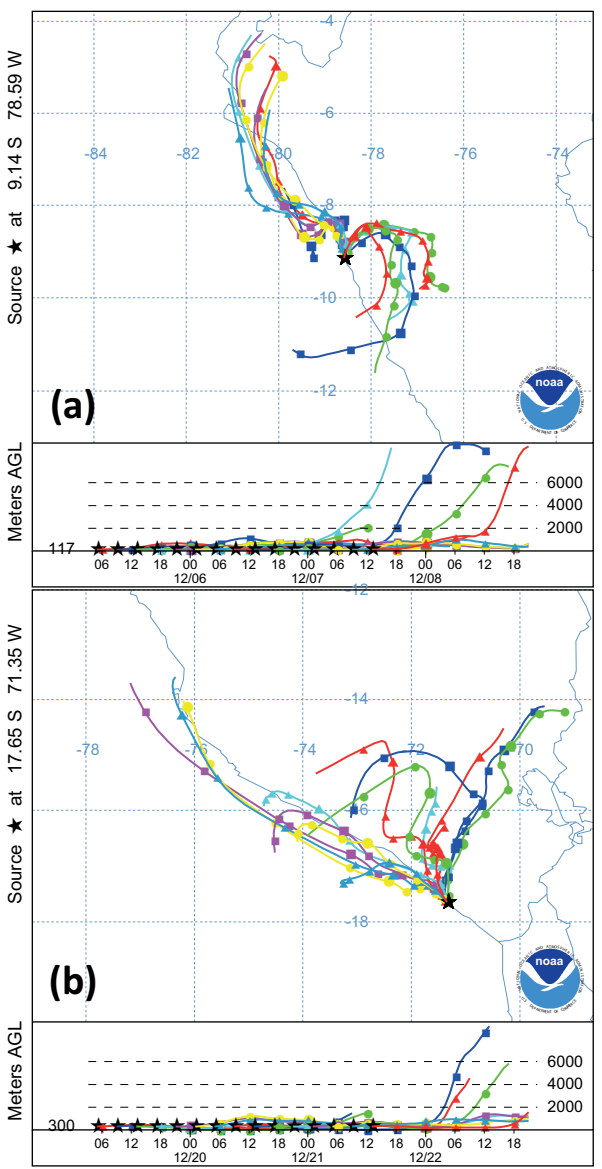

Figure 6. Forward air mass trajectories for the locations of the (a) Chimbote and (b) Ilo metal smelting facilities. Trajectories were run for periods of $48 \mathrm{~h}$ every $4 \mathrm{~h}$ over the collection periods of samples (a) TM02 and (b) TM09.

welling of $120-220 \times 10^{3} \mathrm{~km}^{2}$ (Nixon and Thomas, 2001), this equates to a flux of $\sim 250-450 \mathrm{nmol} \mathrm{m}^{-2} \mathrm{~d}^{-1}$, approximately 3 orders of magnitude greater than our estimates of the dry atmospheric flux (Table 5).

Paytan et al. (2009) estimated $\mathrm{Cu}$ dry deposition to the global ocean using an atmospheric chemistry transport model in an investigation of the potential toxicity of atmospheric $\mathrm{Cu}$ inputs towards marine primary producers. Their estimates of $\mathrm{Cu}$ flux to the tropical eastern Pacific margin appear to be in the range $0.02-0.06 \mathrm{mg} \mathrm{Cu} \mathrm{m}^{-2} \mathrm{yr}^{-1}(0.8$ $2.4 \mathrm{nmol} \mathrm{m}^{-2} \mathrm{~d}^{-1}$ ), roughly an order of magnitude lower than the values calculated for M91. Emissions from copper smelters on the Nazca coast, which were not included in the model of Paytan et al. (2009), may account for the differences between the two deposition estimates.

\section{Conclusions}

We have reported what we believe to be the first study of aerosol soluble TM concentrations over the Peru upwelling 
system. Most TMs (and MIs) analysed show higher concentrations close to the coast north of $13^{\circ} \mathrm{S}$ than further offshore or to the south, in good agreement with the observed spatial distribution of AOD in the region (Hawkins et al., 2010).

Elevated concentrations of $\mathrm{Cu}, \mathrm{Fe}, \mathrm{Co}$, and $\mathrm{Ni}$ at the south of the transect are most likely related to emissions from the metal smelter at Ilo or similar facilities in northern Chile. However, neither air mass back trajectory analysis nor examination of nss- $\mathrm{SO}_{4}^{2-}$ concentrations (as an indicator of smelter $\mathrm{SO}_{2}$ emissions) can confirm this.

Our calculated dry deposition fluxes for s-Fe and s-Cu appear to be somewhat higher than recent modelled estimates of their deposition (Krishnamurthy et al., 2009; Paytan et al., 2009). However, it should be noted that this comparison is necessarily based on only a few observations from a single month, whereas both modelling studies reported annual average values. The ratio of $\mathrm{N}$ to s-Fe in dry deposition during M91 indicates that aerosol inputs constitute a source of excess $\mathrm{Fe}$ (relative to phytoplankton stoichiometric requirements) to the Peru upwelling system. This may be significant as primary production in these waters has been shown to be limited by Fe availability (Bruland et al., 2005; Hutchins et al., 2002), although it appears unlikely that atmospheric deposition is the dominant source of Fe to surface waters here (Chever et al., 2015). Our work does not allow us to assess whether the deposition flux of s-Cu we estimate might lead to potential problems of toxicity in the tropical south-east $\mathrm{Pa}$ cific.

Acknowledgements. Meteor cruise M91 was supported by the BMBF projects SOPRAN II and III (FKZ 03F0611A and FKZ 03F662A). We thank the Peruvian authorities for authorising us to conduct the study in their territorial waters. We also would like to thank our Peruvian colleagues from IMARPE (M. Graco, A. Bernal, G. Flores, and V. León) for their logistical support to our work. Sample analysis was funded by the UK Natural Environment Research Council (NERC) through grant NE/H00548X/1 and by the School of Natural Sciences, University of East Anglia. We gratefully acknowledge the NOAA Air Resources Laboratory for the provision of the HYSPLIT transport and dispersion model and the READY website (http://www.arl.noaa.gov/HYSPLIT.php) and two anonymous reviewers for their comments on our manuscript.

Edited by: A. Engel

\section{References}

Allen, G., Coe, H., Clarke, A., Bretherton, C., Wood, R., Abel, S. J., Barrett, P., Brown, P., George, R., Freitag, S., McNaughton, C., Howell, S., Shank, L., Kapustin, V., Brekhovskikh, V., Kleinman, L., Lee, Y.-N., Springston, S., Toniazzo, T., Krejci, R., Fochesatto, J., Shaw, G., Krecl, P., Brooks, B., McMeeking, G., Bower, K. N., Williams, P. I., Crosier, J., Crawford, I., Connolly, P., Allan, J. D., Covert, D., Bandy, A. R., Russell, L. M., Trembath, J., Bart, M., McQuaid, J. B., Wang, J., and Chand, D.:
South East Pacific atmospheric composition and variability sampled along $20^{\circ} \mathrm{S}$ during VOCALS-REx, Atmos. Chem. Phys., 11, 5237-5262, doi:10.5194/acp-11-5237-2011, 2011.

Baker, A. R., Jickells, T. D., Witt, M., and Linge, K. L.: Trends in the solubility of iron, aluminium, manganese and phosphorus in aerosol collected over the Atlantic Ocean, Mar. Chem., 98, 4358, 2006.

Baker, A. R., Weston, K., Kelly, S. D., Voss, M., Streu, P., and Cape, J. N.: Dry and wet deposition of nutrients from the tropical Atlantic atmosphere: links to primary productivity and nitrogen fixation, Deep-Sea Res. Pt. I, 54, 1704-1720, 2007.

Baker, A. R., Lesworth, T., Adams, C., Jickells, T. D., and Ganzeveld, L.: Estimation of atmospheric nutrient inputs to the Atlantic Ocean from $50^{\circ} \mathrm{N}$ to $50^{\circ} \mathrm{S}$ based on large-scale field sampling: Fixed nitrogen and dry deposition of phosphorus, Global Biogeochem. Cy., 24, GB3006, doi:10.1029/2009GB003634, 2010.

Baker, A. R., Adams, C., Bell, T. G., Jickells, T. D., and Ganzeveld, L.: Estimation of atmospheric nutrient inputs to the Atlantic Ocean from $50^{\circ} \mathrm{N}$ to $50^{\circ} \mathrm{S}$ based on large-scale field sampling: Iron and other dust-associated elements, Global Biogeochem. Cy., 27, 755-767, doi:10.1002/gbc.20062, 2013.

Becagli, S., Sferlazzo, D. M., Pace, G., di Sarra, A., Bommarito, C., Calzolai, G., Ghedini, C., Lucarelli, F., Meloni, D., Monteleone, F., Severi, M., Traversi, R., and Udisti, R.: Evidence for heavy fuel oil combustion aerosols from chemical analyses at the island of Lampedusa: a possible large role of ships emissions in the Mediterranean, Atmos. Chem. Phys., 12, 3479-3492, doi:10.5194/acp-12-3479-2012, 2012.

Boon, R. G. J., Alexaki, A., and Becerra, E. H.: The Ilo Clean Air Project: A local response to pollution control in Peru, Environ. Urban., 13, 215-232, 10.1177/095624780101300217, 2001.

Bruland, K. W., Rue, E. L., Smith, G. J., and DiTullio, G. R.: Iron, macronutrients and diatom blooms in the Peru upwelling regime: brown and blue waters of Peru, Mar. Chem., 93, 81-103, 2005.

Carn, S. A., Krueger, A. J., Krotkov, N. A., Yang, K., and Levelt, P. F.: Sulfur dioxide emissions from Peruvian copper smelters detected by the Ozone Monitoring Instrument, Geophys. Res. Lett., 34, L09801, doi:10.1029/2006GL029020, 2007.

Chance, R., Jickells, T. D., and Baker, A. R.: Atmospheric trace metal concentrations, solubility and deposition fluxes in remote marine air over the south-east Atlantic, Mar. Chem., 177, 45-56, doi:10.1016/j.marchem.2015.06.028, 2015.

Chand, D., Hegg, D. A., Wood, R., Shaw, G. E., Wallace, D., and Covert, D. S.: Source attribution of climatically important aerosol properties measured at Paposo (Chile) during VOCALS, Atmos. Chem. Phys., 10, 10789-10801, doi:10.5194/acp10-10789-2010, 2010.

Chever, F., Rouxel, O. J., Croot, P. L., Ponzevera, E., Wuttig, K., and Auro, M.: Total dissolvable and dissolved iron isotopes in the water column of the Peru upwelling regime, Geochim. Cosmochim. Ac., 162, 66-82, doi:10.1016/j.gca.2015.04.031, 2015.

Dentener, F., Drevet, J., Lamarque, J. F., Bey, I., Eickhout, B., Fiore, A. M., Hauglustaine, D., Horowitz, L. W., Krol, M., Kulshrestha, U. C., Lawrence, M., Galy-Lacaux, C., Rast, S., Shindell, D., Stevenson, D., van Noije, T., Atherton, C., Bell, N., Bergman, Butler, T., Cofala, J., Collins, B., Doherty, R., Ellingsen, K., Galloway, J., Gauss, M., Montanaro, V., Muller, J. F., Pitari, G., Rodriguez, J., Sanderson, M., Solmon, F., Stra- 
han, S., Schultz, M., Sudo, K., Szopa, S., and Wild, O.: Nitrogen and sulfur deposition on regional and global scales: A multimodel evaluation, Global Biogeochem. Cy., 20, GB4003, doi:10.1029/2005GB002672, 2006.

Duce, R. A., Liss, P. S., Merrill, J. T., Atlas, E. L., Buat-Menard, P., Hicks, B. B., Miller, J. M., Prospero, J. M., Arimoto, R., Church, T. M., Ellis, W., Galloway, J. N., Hansen, L., Jickells, T. D., Knap, A. H., Reinhardt, K. H., Schneider, B., Soudine, A., Tokos, J. J., Tsunogai, S., Wollast, R., and Zhou, M.: The atmospheric input of trace species to the world ocean, Global Biogeochem. Cy., 5, 193-259, doi:10.1029/91GB01778, 1991.

Gidhagen, L., Kahelin, H., Schmidt-Thome, P., and Johansson, C.: Anthropogenic and natural levels of arsenic in PM10 in Central and Northern Chile, Atmos. Environ., 36, 3803-3817, doi:10.1016/s1352-2310(02)00284-4, 2002.

Hawkins, L. N., Russell, L. M., Covert, D. S., Quinn, P. K., and Bates, T. S.: Carboxylic acids, sulfates, and organosulfates in processed continental organic aerosol over the southeast $\mathrm{Pa}$ cific Ocean during VOCALS-Rex 2008, J. Geophys. Res., 115, D13201, doi:10.1029/2009JD013276, 2010.

Hutchins, D. A., Hare, C. E., Weaver, R. S., Zhang, Y., Firme, G. F., DiTullio, G. R., Alm, M. B., Riseman, S. F., Maucher, J. M., Geesey, M. E., Trick, C. G., Smith, G. J., Rue, E. L., Conn, J., and Bruland, K. W.: Phytoplankton iron limitation in the Humboldt Current and Peru Upwelling, Limnol. Oceanogr., 47, 997-1011, doi:10.4319/lo.2002.47.4.0997, 2002.

Krishnamurthy, A., Moore, J. K., Mahowald, N., Luo, C., Doney, S. C., Lindsay, K., and Zender, C. S.: Impacts of increasing anthropogenic soluble iron and nitrogen deposition on ocean biogeochemistry, Global Biogeochem. Cy., 23, GB3016, doi:10.1029/2008gb003440, 2009.

Messie, M. and Chavez, F. P.: Seasonal regulation of primary production in eastern boundary upwelling systems, Prog. Oceanogr., 134, 1-18, doi:10.1016/j.pocean.2014.10.011, 2015.

Morton, P., Landing, W. M., Hsu, S. C., Milne, A., Aguilar-Islas, A. M., Baker, A. R., Bowie, A. R., Buck, C. S., Gao, Y., Gichuki, S., Hastings, M., Hatta, M., Johansen, A. M., Losno, R., Mead, C., Patey, M. D., Swarr, G., Vandermark, A., and Zamora, L. M.: Methods for sampling and analysis of marine aerosols: results from the 2008 GEOTRACES aerosol intercalibration experiment, Limnol. Oceanogr.-Methods, 11, 62-78, doi:10.4319/lom.2013.11.62, 2013.

Nixon, S. and Thomas, A.: On the size of the Peru upwelling ecosystem, Deep-Sea Res. Pt. I, 48, 2521-2528, doi:10.1016/S0967-0637(01)00023-1, 2001.

Okin, G., Baker, A. R., Tegen, I., Mahowald, N. M., Dentener, F. J., Duce, R. A., Galloway, J. N., Hunter, K., Kanakidou, M., Kubilay, N., Prospero, J. M., Sarin, M., Surapipith, V., Uematsu, M., and Zhu, T.: Impacts of atmospheric nutrient deposition on marine productivity: roles of nitrogen, phosphorus, and iron, Global Biogeochem. Cy., 25, GB2022, doi10.1029/2010GB003858, 2011.
Paytan, A., Mackey, K. R. M., Chen, Y., Lima, I. D., Doney, S. C., Mahowald, N., Labiosa, R., and Post, A. F.: Toxicity of atmospheric aerosols on marine phytoplankton, P. Natl. Acad. Sci. USA, 106, 4601-4605, 10.1073/pnas.0811486106, 2009.

Raes, F., Van Dingenen, R., Vignati, E., Wilson, J., Putaud, J. P., Seinfeld, J. H., and Adams, P.: Formation and cycling of aerosols in the global troposphere, Atmos. Environ., 34, 4215-4240, 2000.

Rickli, J., Frank, M., Baker, A. R., Aciego, S., de Souza, G., Georg, R. B., and Halliday, A. N.: Hafnium and neodymium isotope distribution in surface waters of the eastern Atlantic Ocean: Implications for sources and inputs of trace metals to the ocean, Geochim. Cosmochim. Ac., 74, 540-557, doi:10.1016/j.gca.2009.10.006, 2010.

Saito, M. A., Moffett, J. W., and DiTullio, G. R.: Cobalt and nickel in the Peru upwelling region: A major flux of labile cobalt utilized as a micronutrient, Global Biogeochem. Cy., 18, GB4030, doi:10.1029/2003GB002216, 2004.

Saukel, C.: Tropical Southeast Pacific continent-ocean-atmosphere linkages since the Pliocene inferred from Eolian dust, Ph. D., Department of Earth Sciences, University of Bremen, 174 pp., 2011.

Sholkovitz, E. R., Sedwick, P. N., Church, T. M., Baker, A. R., and Powell, C. F.: Fractional solubility of aerosol iron: Synthesis of a global-scale data set, Geochim. Cosmochim. Ac., 89, 173-189, doi:10.1016/j.gca.2012.04.022 2012.

Spokes, L. J., Yeatman, S. G., Cornell, S. E., and Jickells, T. D.: Nitrogen deposition to the eastern Atlantic Ocean. The importance of south-easterly flow, Tellus, 52B, 37-49, 2000.

Vedamati, J., Chan, C., and Moffett, J. W.: Distribution of dissolved manganese in the Peruvian Upwelling and Oxygen Minimum Zone, Geochim. Cosmochim. Ac., 156, 222-240, doi:10.1016/j.gca.2014.10.026, 2015.

Wood, R., Mechoso, C. R., Bretherton, C. S., Weller, R. A., Huebert, B., Straneo, F., Albrecht, B. A., Coe, H., Allen, G., Vaughan, G., Daum, P., Fairall, C., Chand, D., Gallardo Klenner, L., Garreaud, R., Grados, C., Covert, D. S., Bates, T. S., Krejci, R., Russell, L. M., de Szoeke, S., Brewer, A., Yuter, S. E., Springston, S. R., Chaigneau, A., Toniazzo, T., Minnis, P., Palikonda, R., Abel, S. J., Brown, W. O. J., Williams, S., Fochesatto, J., Brioude, J., and Bower, K. N.: The VAMOS Ocean-Cloud-AtmosphereLand Study Regional Experiment (VOCALS-REx): goals, platforms, and field operations, Atmos. Chem. Phys., 11, 627-654, doi:10.5194/acp-11-627-2011, 2011. 